\title{
PENGARUH KINERJA KEUANGAN TERHADAP PERTUMBUHAN EKONOMI PERKOTAAN DI SULA WESI UTARA TAHUN 2004 - 2014
}

\author{
Greydi Normala Sari, Paulus Kindangen, Tri Oldy Rotinsulu \\ Fakultas Ekonomi dan Bisnis, Magister Ilmu Ekonomi \\ Universitas Sam Ratulangi, Manado
}

\begin{abstract}
ABSTRAK
Pembangunan merupakan suatu rangkaian proses perubahan menuju keadaan yang lebih baik dalam upaya meningkatkan kesejahteraan masyarakat, hal ini dapat terwujud dengan peningkatan taraf hidup masyarakat yang diukur dengan peningkatan laju pertumbuhan ekonomi. Pertumbuhan ekonomi dapat berjalan dengan baik apabila didukung dengan laporan keuangan yang transparan dan akuntable yang dapat diukur dengan kinerja keuangan daerah.

Penelitian ini bertujuan untuk mengetahui pengaruh kinerja keuangan terhadap pertumbuhan ekonomi dengan menggunakan rasio-rasio keuangan untuk mengukur kinerja keuangan, mulai dari rasio kemandirian, rasio ketergantungan, dan rasio efektifitas sebagai variabel bebas dan pertumbuhan ekonomi sebagai variabel terikat. Penelitian ini mengambil sampel observasi di kota Manado, Bitung, Tomohon, dan Kotamobagu. Metode analisis yang digunakan adalah data panel dengan menggabungkan antara cross section dan time series. Model yang digunakan adalah random effect melalui pengujian hausman, sementara untuk pengujian secara ekonometrika dilakukan uji asumsi klasik, dan untuk uji hipotesisnya menggunakan uji- $t$ untuk menguji pengaruh variabel secara parsial, uji - $F$ untuk menguji pengaruh variabel secara serempak, uji koefisien determinasi $\left(R^{2}\right)$ untuk menguji kemampuan model regresi dalam menerangkan variasi variabel terikat.

Berdasarkan penelitian diperoleh hasil bahwa rasio kemandirian memiliki pengaruh yang positif dan signifikan terhadap pertumbuhan ekonomi, rasio efektifitas juga berpengaruh positif dan signifikan terhadap pertumbuhan ekonomi sedangkan rasio ketergantungan berpengaruh negatif dan signifikan hal ini telah sesuai dengan teori.
\end{abstract}

Kata Kunci : PDRB, Rasio Kemandirian, Rasio Ketergantungan, dan Rasio Efektifitas

\section{ABSTRACT}

The construction is a series of processes of change towards a better state in an effort to improve the welfare of society, this can be realized by improving standards of living as measured by the increase in the rate of economic growth. Economic growth can run well when supported with financial reports transparent and accountable can be measured by financial performance area.

This research aims to determine the effect on the economic growth of financial performance using financial ratios to measure financial performance, ranging from self-sufficiency ratio, the dependency ratio, and the ratio of effectiveness as independent variables and economic growth as the dependent variable. This study took a sample of observations in the city of Manado, Bitung, Tomohon, and Kotamobagu. The analytical method used is the panel data by combining cross section and time series. The model used is the random effect through Hausman test, while for econometric testing performed classical assumption, and to test the hypothesis using $t$-test to examine the effect of partial variables, test - F to test the effect of variables simultaneously, test the coefficient of determination ( R2 ) to test the ability of the regression model in explaining the variation of the dependent variable.

Based on the research results that independence ratio has a positive and significant effect on economic growth , effectiveness ratio was also positive and significant impact on economic growth, while the dependency ratio and significant negative effect it has in accordance with the theory..

Keywords : GRDP, Independence ratio, dependency ratio, and effectiveness ratio.

\section{PENDAHULUAN}

\section{Latar Belakang Permasalahan}

Pembangunan merupakan suatu rangkaian proses perubahan menuju keadaan yang lebih baik dalam upaya meningkatkan kesejahteraan masyarakat. Menurut Samuelson dan Nordhaus (2004), salah satu indikator makro keberhasilan pembangunan diantaranya dilihat dari pertumbuhan ekonomi yang menunjukkan barang dan jasa yang dihasilkan suatu daerah. Faktor yang dapat mendorong pertumbuhan 
ekonomi, antara lain ketersediaan sumberdaya manusia, sumberdaya alam, pembentukan modal, dan teknologi.

Berdasarkan Propenas, Pembangunan ekonomi adalah suatu upaya dalam rangka mendukung pelaksanaan salah satu hal penting yang tercantum dalam prioritas pembangunan nasional, yaitu mempercepat pemulihan ekonomi dan memperkuat landasan pembangunan ekonomi berkelanjutan dan berkeadilan berdasarkan sistem kerakyatan. Penetapan prioritas tersebut didasarkan pada masalah dan tantangan yang dihadapi, serta arah kebijakan dalam pembangunan ekonomi, baik pembangunan jangka pendek maupun jangka menengah. (Kuncoro, 2007)

Pembangunan daerah merupakan bagian integral dari pembangunan nasional yang dilaksanakan berdasarkan prinsip otonomi daerah dan pengaturan sumberdaya nasional yang memberikan kesempatan bagi peningkatan demokrasi dan kinerja daerah untuk meningkatkan kesejahteraan masyarakat menuju masyarakat madani yang bebas kolusi, korupsi dan nepotisme. Penyelenggaraan pemerintah daerah sebagai subsistem negara dimaksudkan untuk meningkatkan daya guna dan hasil guna penyelenggaraan pemerintahan dan pelayanan masyarakat. Sebagai daerah otonom, kabupaten/kota untuk bertindak sebagai pelaksana, sedangkan pemerintah Provinsi sebagai koordinator mempunyai kewenangan dan tanggung jawab menyelenggarakan kepentingan masyarakat berdasarkan prinsip-prinsip keterbukaan, partisipasi masyarakat, dan pertanggungjawaban kepada masyarakat (Arsa, 2015)

Sejak timbulnya krisis ekonomi yang dipicu oleh krisis moneter pertengahan 1997, pembangunan di Indonesia terhenti karena ketidakmampuan pemerintah dalam membiayai proyek-proyek pembangunan yang disebabkan pendapatan pemerintah berkurang, khususnya dari sektor pajak dan retribusi. Krisis ekonomi telah berhasil memunculkan kepermukaan beberapa kelemahan perekonomian nasional. Berbagai distorsi atau ketidaksempurnaan pasar yang membuat kondisi ekonomi tidak efisien sehingga menggangu agen ekonomi dalam memaksimalkan kesejahtraan sosial, yang terjadi pada masa sebelumnya telah melemahkan ketahanan ekonomi nasional dalam menghadapi krisis, menimbulkan berbagai bentuk kesenjangan sosial dan menghambat kemampuan untuk mengatasi krisis dengan cepat. Kurang meratanya penyebaran pembangunan membuat kesenjangan pertumbuhan antardaerah, antaraperkotaan dan perdesaan, antarkawasan seperti kawasan barat dan kawasan timur Indonesia, maupun antargolongan masyarakat sehingga gejolak sosial mudah terjadi. Untuk mengurangi masalah serta gejolak-gejolak sosial yang akan terjadi maka suatu daerah diberikan wewenang untuk mengelola daerahnya sendiri agar pembangunan didaerahnya dapat berjalan seiring dengan pembangunan dipusat, hal ini disebut dengan otonnomi daerah.

Otonomi daerah dapat diartikan sebagai kewajiban yang diberikan kepada daerah otonom untuk mengelola sendiri urusan pemerintahan dan kepentingan masyarakat setempat sesuai dengan peraturan perundang-undangan. Salah satu faktor penyelenggaraan otonomi daerah adalah agar pembangunan di daerah berjalan seiring dengan pembangunan di pusat. Ini merupakan bentuk koreksi atas pelaksanaan pembangunan ekonomi yang selama ini menitikberatkan pembangunan di pusat dan kurang memperhatikan perkembangan pembangunan daerah. Dengan adanya otonomi daerah bermaksud untuk memeperbaiki kekeliruan selama ini dengan cara memberikan peluang kepada daerah untuk mendapatkan dana lebih besar dan kebebasan untuk mengelola keuangannya sendiri.

Paradigma pengelolaan keuangan daerah telah mengalami perubahan yang sangat mendasar sejak diterapkan otonomi daerah pada tahun 2001. Undang-undang (UU) No.32 Tahun 2004 dan UU No.33 Tahun 2004 yang menjadi landasan utama dalam pelaksanaan otonomi daerah pada hakekatnya memberikan peluang yang lebih besar kepada daerah untuk lebih mengoptimalkan potensi yang dimiliki daerah, baik yang menyangkut sumberdaya manusia, dana, maupun sumberdaya lain yang merupakan kekayaan daerah. Dengan otonomi daerah, pemerintah daerah diharapkan semakin mandiri, mengurangi ketergantungan terhadap pemerintah pusat, baik dalam hal pembiayaan pembangunan maupun dalam hal pengelolaan keuangan daerah (Sularso dan Restianto, 2011).

Pengelolaan keuangan daerah yang dilakukan secara ekonomis, efisien, dan efektif atau memenuhi prinsip value for money serta partisipasi, transparansi, akuntabilitas, dan keadilan akan dapat mendorong pertumbuhan ekonomi. Pengelolaan keuangan daerah yang baik tidak hanya membutuhkan sumberdaya manusia yang handal, tetapi juga harus didukung oleh kemampuan keuangan daerah yang memadai. Tingkat kemampuan keuangan daerah salah satunya dapat diukur dari besarnya penerimaan daerah, khususnya pendapatan asli daerah. Pengukuran kinerja keuangan pada pemerintah daerah juga digunakan untuk menilai 
akuntabilitas dan kemampuan keuangan daerah dalam penyelenggaraan otonomi daerah. Munculnya Undang-undang nomor 22 tahun 1999 tentang Pemerintahan Daerah dan Undang-undang nomor 25 tahun 1999 tentang Perimbangan Keuangan Antara Pemerintah Pusat dan Daerah, adalah jawaban atas permasalahan tersebut.

Pemberian kewenangan yang luas, nyata dan bertanggungjawab yang tersirat dalam perundangan tersebut, adalah pencerminan proses demokratisasi dalam pelaksanaan otonomi daerah untuk membantu pemerintah pusat dalam menyelenggarakan pemerintahan di daerah dengan menitikberatkan kepada pemerintah kabupaten/kota. Secara yuridis, pelaksanaan otonomi yang luas dan nyata tersebut bukan merupakan kelanjutan, tetapi secara faktual empiris, merupakan kesinambungan dari pelaksanaan otonomi daerah berdasarkan UU nomor 5 tahun 1974 dan bahkan peraturan sebelumnya. Jadi tujuan kebijakan desentralisasi adalah mewujudkan keadilan antara kemampuan dan hak daerah; peningkatan pendapatan asli daerah dan pengurangan subsidi dari pusat, mendorong pembangunan daerah sesuai dengan aspirasi masingmasing daerah.

Otonomi fiskal daerah merupakan salah satu aspek penting dari otonomi daerah secara keseluruhan, karena pengertian otonomi fiskal daerah menggambarkan kemampuan pemerintah daerah dalam meningkatkan PAD seperti pajak, retribusi dan lain-lain. Namun harus diakui bahwa derajat otonomi fiskal daerah di Indonesia masih rendah, artinya daerah belum mampu membiayai pengeluaran rutinnya. Karena itu otonomi daerah bisa diwujudakan hanya apabila disertai keuangan yang efektif. Pemerintah daerah secara finansial harus bersifat independen terhadap pemerintah pusat dengan jalan sebanyak mungkin menggali sumber-sumber PAD (Radianto, 1997 ; A Halim , 2001).

Untuk dapat meningkatkan investasi, maka kemampuan keuangan daerah juga harus memadai. Indikator besar kecilnya investasi daerah adalah tingginya rasio belanja modal dalam APBD. Alokasi belanja modal pada pemerintah daerah juga dipengaruhi oleh baik tidaknya kinerja keuangan daerah, seperti derajat desentralisasi, ketergantungan keuangan, kemandirian keuangan, efektivitas Pendapatan Asli Daerah (PAD), dan derajat kontribusi Badan Usaha Milik Daerah (BUMD). Dengan demikian terdapat keterkaitan antara pertumbuhan ekonomi daerah dengan kinerja keuangan (Arsa, 2015).

Selama tahun 2011-2014, secara umum laju pertumbuhan ekonomi perkotaan disulawesi utara mengalami fluktuasi, seperti yang telah terlampir pada tabel dibawah ini dimana kota manado pada tahun 2011 yang terus meningkat dari 7,30\% sampai pada tahun 2012 sebesar 8,71\%, kemudian mengalami penurunan pada tahun 2013 sebesar 8,57\% sampai 6,48\% pada tahun 2014. Kota Bitung memiliki Laju pertumbuhan ekonomi ditahun 2011 sebesar 7,76\% meningkat menjadi 7,98\% ditahun 2012 dan kemudian menurun pada tahun 2013 sebesar 7,92\% sampai 6,48\% ditahun 2014, hal serupa juga diikuti oleh kota-kota lainnya seperti tomohon dan kotamobagu, untuk kota tomohon pada tahun 2011 dengan laju 6,43\% meningkat hingga 6,93\% ditahun 2013 kemudian mengalami penurunan sebesar 6,22\% ditahun 2014,disusul dengan kotamobagu yang tidak jauh berbeda dari kota tomohon yang juga mengalami fluktuasi laju pertumbuhan ekonomi sebesar 7,05\% pada tahun 2011 hingga 7,78\% ditahun 2013 dan menurun ditahun 2014 sebesar $6,69 \%$. Penelitian ini difokuskan untuk mengetahui peran kinerja keuangan daerah terhadap pertumbuhan ekonomi. Memang banyak faktor yang dapat mempengaruhi proses penyusunan anggaran hingga munculnya berbagai masalah-masalah, di antaranya kondisi keuangan daerah, kepentingan pribadi (private interest), kepentingan politik, perilaku oportunistik, moral, dan sebagainya. Namun dari sekian banyak faktor, yang mudah diukur (observable) adalah faktor yang berasal dari keuangan daerah itu sendiri, jadi penelitian ini akan mengambil variabel yang berasal dari keuangan daerah, yaitu kinerja keuangan daerah perkotaan disulawesi utara yang terdiri dari kota manado, bitung, tomohon, dan kotamobagu. Kinerja keuangan daerah dalam penelitian ini diukur berdasarkan rasio kemandirian, rasio ketergantungan, dan rasio efektivitas sedangkan pertumbuhan ekonomi pada penelitian ini diukur dengan tingkat PDRB pada harga konstan.

\section{Rumusan Masalah}

Berdasarkan uraian latar belakang pembahasan diatas, maka rumusan masalah dalam penelitian ini adalah:

1. Apakah rasio kemandirian di perkotaan sulawesi utara berpengaruh terhadap pertumbuhan ekonomi?

2. Apakah rasio ketergantungan di perkotaan sulawesi utara berpengaruh terhadap pertumbuhan ekonomi?

3. Apakah rasio efektivitas di perkotaan sulawesi utara berpengaruh terhadap pertumbuhan ekonomi? 


\section{Tujuan Penelitian}

Berdasarkan rumusan masalah di atas, maka tujuan penelitian ini adalah:

1. Untuk mangetahui pengaruh rasio kemandirian terhadap pertumbuhan ekonomi di perkotaan sulawesi utara.

2. Untuk mangetahui pengaruh rasio ketergantungan terhadap pertumbuhan ekonomi di perkotaan sulawesi utara.

3. Untuk mangetahui pengaruh rasio efektivitas terhadap pertumbuhan ekonomi di perkotaan sulawesi utara.

\section{Manfaat Penelitian}

Penelitian ini diharapkan akan memberikan faedah atau manfaat sebagai berikut:

1. Secara teoritis penelitian ini diharapkan dapat memberikan kontribusi bagi pengembangan ilmu pengetahuan, khususnya yang terkait dengan kinerja keuangan daerah, dan pertumbuhan ekonomi.

2. Hasil penelitian ini diharapkan dapat dijadikan bahan pertimbangan bagi para pengambil kebijakan dijajaran pemerintahan kota disulawesi utara dalam menetapkan kebijakan pembangunan ekonomi daerah, khususnya masalah kinerja keuangan dan pertumbuhan ekonomi.

\section{Landasan Teori \\ Otonomi Daerah}

Pemberlakuan otonomi daerah yang dimulai sejak tanggal 1 Januari 2001 telah membawa implikasi yang luas dan serius. UU No.22 tahun 1999 tentang Pemerintah Daerah dan direvisi menjadi UU No.32 Tahun 2004 telah melahirkan paradigma baru dalam pelaksanaan otonomi daerah, yang meletakkan otonomi penuh, luas dan bertanggung jawab pada daerah kabupaten dan kota. Perubahan ini dimaksudkan untuk meningkatkan efektivitas pelayanan masyarakat, menumbuhkan semangat demokratisasi dan pelaksanaan pembangunan daerah secara berkelanjutan, dan lebih jauh diharapkan akan menjamin tercapainya keseimbangan kewenangan dan tanggung jawab antara pusat dan daerah (Nurlin Muhammad).

\section{Kinerja Keuangan}

Kinerja dapat diartikan sebagai hasil kerja. Kata kinerja (performance) dalam konteks tugas, sama dengan prestasi kerja. Pengertian kinerja dalam organisasi merupakan jawaban dari berhasil atau tidaknya tujuan organisasi yang telah ditetapkan. Pengertian kinerja (performance) adalah gambaran mengenai tingkat pencapaian pelaksanaan suatu kegiatan program/kebijakan dalam mewujudkan sasaran, tujuan, misi, dan visi organisasi yang tertuang dalam strategic planning suatu organisasi.

Permendagri No. 13 Tahun 2006 menyebutkan pengertian kinerja sebagai berikut, kinerja adalah keluaran/hasil dari kegiatan /program yang akan atau telah dicapai sehubungan dengan penggunaan anggaran dengan kuantitas dan kualitas yang terukur. Dari berbagai pengertian tersebut, kinerja menekankan apa yang dihasilkan dari fungsi-fungsi suatu pekerjaan. Bila disimak lebih lanjut apa yang terjadi dalam sebuah pekerjaan adalah suatu proses yang mengolah input menjadi output (hasil kerja).

Kinerja keuangan adalah suatu ukuran kinerja yang menggunakan indikator keuangan. Analisis kinerja keuangan pada dasarnya dilakukan untuk menilai kinerja di masa lalu dengan melakukan berbagai analisis, sehingga diperoleh posisi keuangan yang mewakili realitas entitas dan potensi-potensi kinerja yang akan berlanjut. Menurut Halim (2008) analisis keuangan adalah usaha mengidentifikasi ciri-ciri keuangan berdasarkan laporan keuangan yang tersedia. Kinerja keuangan daerah sebenarnya dapat diproksikan oleh berbagai macam indikator, di antaranya rasio tingkat kemandirian, rasio tingkat ketergantungan, rasio efektifitas PAD, rasio efisiensi, rasio kontribusi laba BUMD, efektifitas belanja, debt service coverage ratio (DSCR), rasio tingkat pembiayaan SiLPA, rasio ruang fiskal, dan sebagainya. Namun dalam penelitian ini hanya menggunakan 3 indikator yaitu rasio tingkat kemandirian, rasio tingkat ketergantungan, dan rasio efisiensi. 
Analisis keuangan menurut Halim (2002) merupakan sebuah usaha mengidentifikasi ciri-ciri keuangan berdasarkan laporan keuangan yang tersedia. Sedangkan pada Pasal 4 Peraturan Pemerintah Nomor 58 Tahun 2005 tentang pengelolaan keuangan daerah menegaskan bahwa keuangan daerah dikelola secara tertib, taat pada peraturan perundang-undangan, efisien, ekonomis, efektif, transparan, dan bertanggungjawab dengan memperhatikan asas keadilan, kepatutan, dan manfaat untuk masyarakat. Pemerintah daerah sebagai pihak yang diberikan tugas menjalankan pemerintahan, pembangunan, dan pelayanan masyarakat wajib melaporkan pertanggungjawaban keuangan daerah sebagai dasar penilaian kinerja keuangannya. Salah satu alat untuk menganalisis kinerja pemerintah daerah dalam mengelola keuangan daerahnya adalah dengan melakukan analisis rasio keuangan terhadap APBD yang telah ditetapkan dan dilaksanakannya (Halim, 2007).

\section{Pertumbuhan Ekonomi}

Secara umum pertumbuhan ekonomi dapat diartikan sebagai perkembangan kegiatan dalam perekonomian yang menyebabkan barang dan jasa yang diproduksi dalam masyarakat bertambah dan kemakmuran masyarakat meningkat. Pertumbuhan ekonomi dapat juga diartikan sebagai kenaikan Gross Domestic Product (GDP) atau Gross National Product (GNP) tanpa memandang apakah kenaikan itu lebih besar atau lebih kecil dari tingkat pertumbuhan penduduk atau apakah perubahan struktur ekonomi terjadi atau tidak (Arsyad, 1999). Todaro (1997) dalam Adi (2007) secara spesifik menyebutkan ada tiga faktor atau komponen utama pertumbuhan ekonomi, yaitu akumulasi modal, pertumbuhan penduduk, dan hal-hal yang berhubungan dengan kenaikan jumlah angkatan kerja yang dianggap secara positif merangsang pertumbuhan ekonomi.

Pertumbuhan ekonomi juga didefinisikan merupakan sebagai suatu proses perubahan kondisi perekonomian disuatu Negara yang berkesinambungan menuju keadaan yang lebih baik selama periode tertentu. Menurut Sukirno (2000) pertumbuhan ekonomi berarti perkembangan kegiatan dalam perekonomian yang menyebabkan barang dan jasa yang diproduksikan dalam masyarakat bertambah dan kemakmuran masyarakat meningkat. Sehingga pertumbuhan ekonomi dapat diartikan juga sebagai proses kenaikan kapasitas produksi suatu perekonomian yang diwujudkan dalam bentuk kenaikan pendapatan nasional. Adanya pertumbuhan ekonomi merupakan indikasi keberhasilan pembangunan ekonomi. Teori dibangun berdasarkan pengalaman empiris, sehingga teori dapat dijadikan sebagai dasar untuk memprediksi dan membuat suatu kebijakan Secara umum Teori pertumbuhan ekonomi menurut para ahli dapat dibagi menjadi, Teori pertumbuhan ekonomi historis, merkantilis dan teori pertumbuhan ekonomi klasik dan neoklasik.

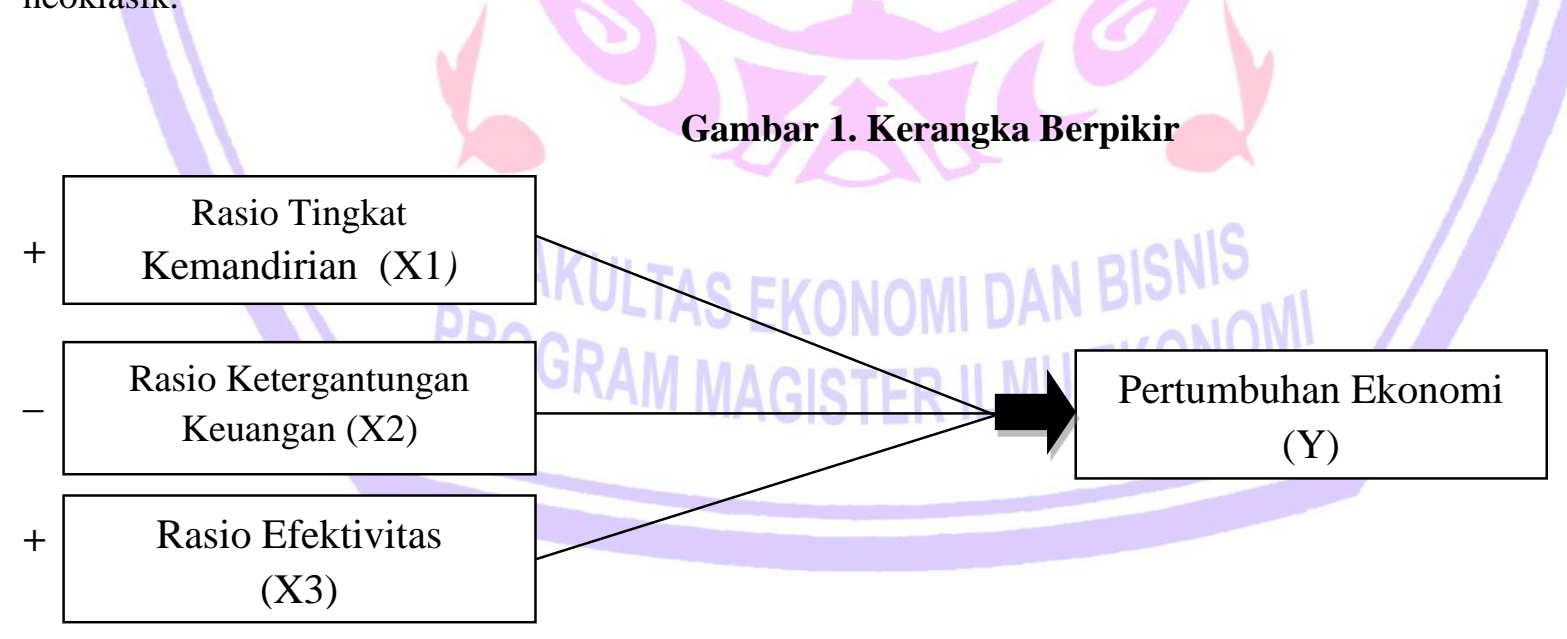

\section{METODE PENELITIAN}




\section{Jenis dan Sumber Data}

Jenis data yang digunakan dalam penelitian ini adalah data sekunder kinerja keuangan perkotaan disulawesi utara, terdiri dari kota manado, bitung, tomohon, dan kotamobagu yang meliputi rasio kemandirian, rasio ketergantungan, rasio efektivitas dan pertumbuhan ekonomi pada tahun 2010 sampai 2014 (tahunan) dengan menggunakan data panel. Data tersebut diolah kembali sesuai dengan kebutuhan model yang digunakan. Sumber data berasal dari berbagai sumber, antara lain yang diperoleh dari Badan Pusat Statistik, BAPEDDA dan jurnal-jurnal ilmiah serta literatur-literatur lain yang berkaitan dengan topik penelitian ini.

\section{Metode Analisis}

1. Kualitatif dilakukan dengan menggunakan beberapa instrumen analisis seperti tabel dan grafik serta analisis rasio-rasio yang dapat mencerminkan uraian analisis penelitian secara teratur dan saling mendukung.

2. Kuantitatif dilakukan dengan menggunakan model ekonometrika dengan bantuan program Eviews 8 dan Microsoft Excel.

\section{Metode Analisis Rasio}

Dalam penelitian ini menggunakan metode analisis kualitatif untuk mengetahui performa keuangan daerah melalui perhitungan rasio-rasio keuangan.

\section{Rasio Derajat Desentralisasi}

Rasio ini menunjukan derajat kontribusi PAD terhadap total penerimaan daerah. Semakin tinggi kontribusi PAD maka semakin tinggi kemampuan pemerintah daerah dalam penyelenggaraan desentralisasi.

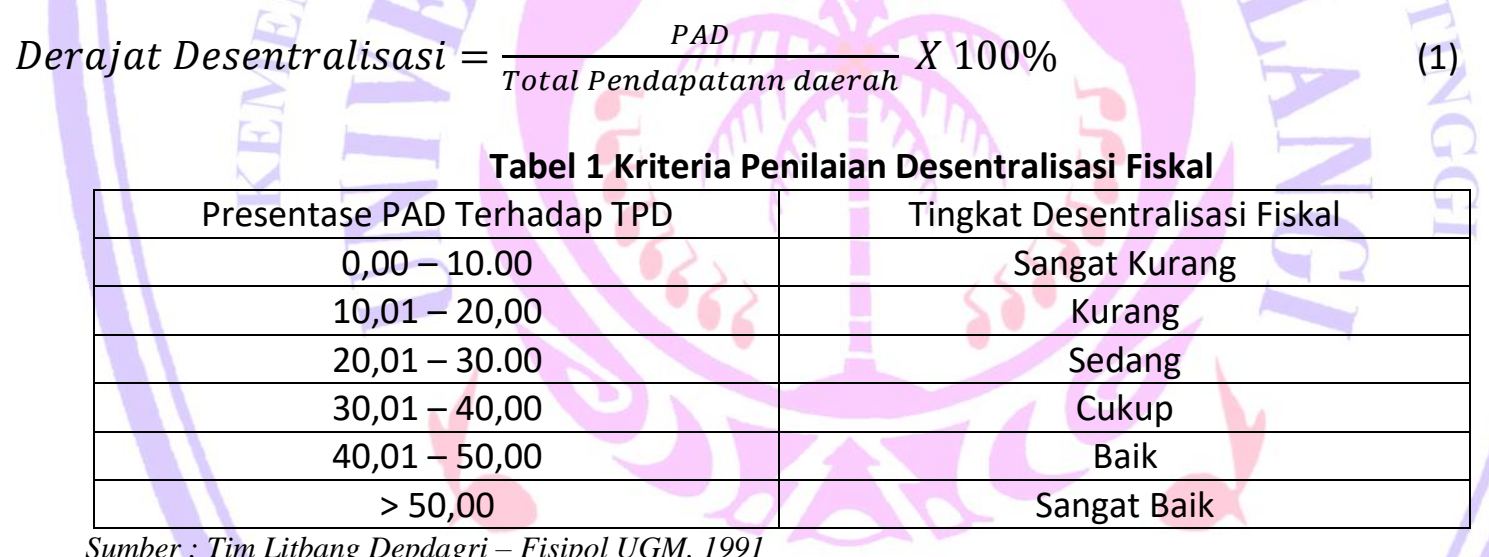

Metode kuatitatif atau metode ekonometrika merupakan hasil dari suatu tinjauan tertentu tentang peran ilmu ekonomi, mencakup aplikasi statistik matematik atas data ekonomi guna memberikan dukungan empiris terhadap model yang disusun berdasarkan metematika ekonomi serta memperoleh hasil berupa angka-angka.

Metode analisis ekonometrik yang akan digunakan dalam penelitian ini adalah model regresi data panel yang merupakan gabungan antara data runtut waktu (time series) dan data silang (cross section). Data runtut waktu biasanya meliputi satu objek/individu (misalnya PAD atau PDRB), tetapi meliputi beberapa. Data silang terdiri dari atas beberapa atau banyak objek.

Ada beberapa keuntungan yang diperoleh dengan menggunakan data panel. Pertama, data panel yang merupakan gabungan dua data yaitu time series dan cross section mampu menyediakan data yang lebih banyak sehingga akan menghasilkan degree of freedom yang lebih besar. Kedua, menggabungkan informasi dari data time series dan cross section dapat mengatasi masalah yang timbul ketika ada masalah penghilangan variabel (ommited-variable) (Widarjono, 2013).

\section{Fungsi persamaan data panel}

Fungsi persamaan regresi linear menggunakan data cross section dan time series:

$$
\text { Yit }=\beta_{\mathrm{o}}+\beta_{1} \mathrm{X} 1 \text { it }+\beta_{2} \mathrm{X} 2 \text { it }+\beta_{3} \mathrm{X} 3 \text { it }+ \text { eit. } \quad \mathrm{i}=1,2, \ldots \mathrm{N}: \mathrm{t}=1,2, \ldots \mathrm{T}
$$


Keterangan :

$\mathrm{N}=$ Banyaknya observasi

$\mathrm{T} \quad=$ Banyaknya waktu

I $\quad=$ Data cross section

$\mathrm{Nx} \mathrm{T}=$ Banyaknya data panel

Berdasarkan fungsi persamaan diatas, model regresi yang digunakan dalam penelitian ini adalah model LOG-LIN atau model pertumbuhan dimana variable terikatnya berbentuk logaritma namun variable bebasnya berbentuk linear. Persamaan regresi ini ditransformasikan ke logaritma linear dengan menggunakan logaritma natural $(\mathrm{ln})$, logaritma terhadap basis $e$. variabel yang masih bersatuan jutaan rupiah di transformasikan kedalam satuan persen (\%) mengikuti variable lainnya yang telah dalam bentuk persen. model ini merupakan model regresi linear karena variabel $\mathrm{Y}$ telah disetarakan dengan variable $\mathrm{X}$ lainnya, dinyatakan dalam bentuk logaritma. karena bentuk linearitasnya, maka model ini disebut log-lin atau model pertumbuhan. (Gujarati.2006)

Dalam model ini, koefisien kemiringan parsial $\beta_{1}, \beta_{2}$, dan $\beta_{3}$ disebut sebagai koefisien elastisitas parsial, tiap koefisisen kemiringan parsial mengukur elastisitas parsial dari variabel tak bebas terhadap variabel penjelas yang bersangkutan, dengan mempertahankan semua varibel lain pada tingkat yang konstan. Model ini disebut sebagai Model Regresi Berganda Log-lin. berikut:

Persamaan (2) data panel ditransformasikan dalam bentuk log sehingga menjadi linear. Sebagai

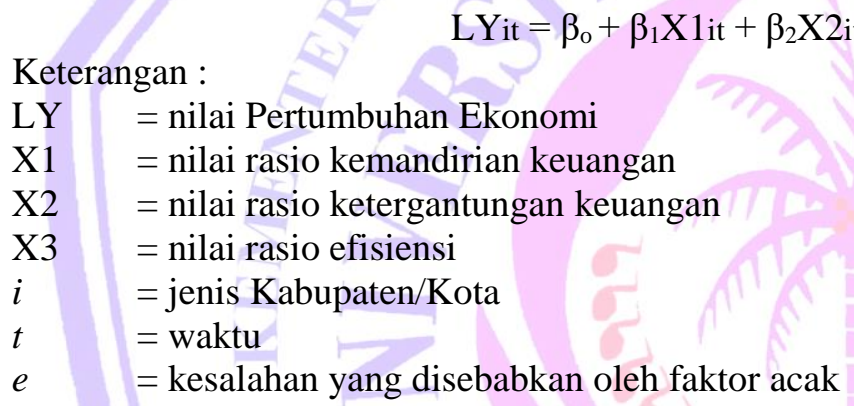

$\beta_{1}, \beta_{2}, \beta_{3}, \beta_{4}=$ koefisien regresi sekaligus koefisien elastisitas

Alasan menggunakan analisis regresi dalam transformasi log adalah (Gujarati, 1999) :

1. Parameter $(\beta)$ dapat langsung menunjukkan koefisien elastisitas, yaitu persentase perubahan dalam variabel terikat untuk persentase perubahan tertentu dalam variabel bebas.

2. Gejala heterokedastisitas dapat dikurangi karena transformasi logaritma akan dapat memperkecil skala variabel-variabel yang diukur.

Sebelum melakukan interpretasi terhadap hasil regresi dari model yang akan digunakan, terlebih dahulu dilakukan pengujian terhadap asumsi klasik. Hal ini dilakukan untuk mengetahui apakah model tersebut dapat dianggap relevan atau tidak. Pengujian yang dilakukan meliputi uji terhadap gejala heterokedastisitas, autokorelasi, dan mutikolinearitas. Selain itu, juga dilakukan pengujian secara statistika yang meliputi uji signifikansi parameter individu (uji statistik t), signifikansi simultan (uji statistik F), dan uji koefisien determinasi $\left(\mathrm{R}^{2}\right)$,

\section{Common Effect ( koefisien tetap antar waktu dan individu)}

Merupakan metode dengan hanya menggabungkan data time series dan cross section tanpa harus melihat perbedaan antarwaktu dan individu, maka kita bias menggunakan metode OLS untuk mengestimasi model data panel (Widarjono,2013).

Fixed Effect (model efek tetap)

Model fixed effect adalah teknik mengestimasi data panel dengan menggunakan variable dummy untuk menangkap adanya perbedaan intersep. Pengertian ini didasarkan adanya perbedaan intersep antara 
perusahaan namun intersepnya sama antar waktu (time invariant). Model ini juga mengasumsikan bahwa koefisien regresi (slope) tetap antar perusahaan dan antar waktu. (Widarjono,2013)

\section{Random Effect (model efek acak)}

Random effect atau model efek acak diestimasikan pada data panel yang variabel residual diduga memiliki hubungan antar waktu dan antar subjek. Menurut Widarjono (2009) model random effect digunakan untuk mengatasi kelemahan model fixed effect yang menggunakan variabel dummy. Metode analisis data panel dengan model random effect harus memenuhi persyaratan yaitu jumlah cross section harus lebih besar daripada jumlah variabel penelitian. Persamaan model random effect menurut Gujarati (2012) adalah sebagai berikut:

$$
y_{i t}=\alpha+x_{i t}^{\prime} \beta+W_{i t}
$$

Dimana $W_{i t}$ terdiri dari dua komponen yaitu residual cross section dan residual gabungan time series dan cross section. Model ini disebut juga Error Components Model (ECM) karena residual terdiri atas 2 komponen. Berbeda dengan fixed effects model, efek spesifik dari masing-masing individu diperlakukan sebagai bagian dari komponen error yang bersifat acak dan tidak berkorelasi dengan variabel penjelas yang teramati, karena itu metode OLS tidak bisa digunakan untuk mendapatkan estimator yang efisien bagi model random effect. Metode yang tepat untuk mengestimasi model random effects adalah Generalized Least Squares (GLS) dengan asumsi homokedastik dan tidak ada cross-sectional correlation.

\section{Pemilihan teknik estimasi data panel}

Dari ketiga model yang telah diestimasi akan dipilih model yang paling tepat sesuai dengan tujuan penelitian, ada tiga pengujian yang dapat dijadikan alat dalam memilih model regresi data panel common effect (CE), fixed effect (FE), atau random effect (RE) yaitu dengan uji statistic F (Chow test), Haustman Test, dan Langrange Multiplier (LM) test.

\section{Uji statistic F (Chow Test)}

Dilakukan untuk membandingkan atau memilih model mana yang terbaik antara CE dan FE. Perhatiakan nilai probabilitas, untuk cross section $\mathrm{F}$, jika nilainya $>0,05$ maka model yang dipilih adalah $\mathrm{CE}$, tetapi jika prob cross section $\mathrm{F}<0.05$ maka model yang terpilih adalah $\mathrm{FE}$.

\section{Uji Haustman}

Dilakukan untuk membandingkan atau memilih model mana yang terbaik antara FE dan RE. jika nilai probabilitas cross section random $>0,05$ maka model yang digunakan adalah RE, tetapi jika probabilitas cross section random $<0,05$ maka model yang terpilih adalah model FE.

\section{Uji Asumsi Klasik}

\section{Uji Heterokedastisitas}

Salah satu asumsi pokok dalam model regresi linear klasik adalah bahwa varian setiap disturbance term yang dibatasi oleh nilai tertentu mengenai variabel-variabel bebas adalah berbentuk suatu nilai konstan yang sama dengan $\sigma 2$. Inilah yang disebut asumsi heteroskedasticity atau varian yang sama.

Dalam heteroskedastisitas menunjukkan disturbance yang dapat ditunjukkan dengan adanya conditional variance Yi bertambah pada waktu X bertambah. Dapat dikatakan bahwa heteroskedastisitas menyebabkan penaksiran koefisien-koefisien regresi menjadi tidak efisien. Hasil taksiran dapat menjadi kurang dari semestinya, melebihi dari semestinya dan menyesatkan.

Salah satu cara untuk mendeteksi ada atau tidaknya gejala heteroskedastisitas maka dapat dilakukan dengan menggunakan White Test. Pengujian ini dilakukan dengan cara melihat probabilitas $O b s * R$-squared. Apabila nilai probabilitas $O b s^{*} R$-squared lebih besar dari taraf nyata tertentu maka persamaan tersebut tidak mengandung gejala heteroskedastisitas, begitu juga sebaliknya.

Pengujian ini dapat ditentukan berdasarkan hipotesis berikut:

- Ho : Jika chi-square hitung yaitu probabilitas $O b s * R$-squared < nilai kritis $\quad$ chi-squares pada tabel dengan derajat kepercayaan tertentu menunjukan tidak adanya heteroskedastisitas 
- H1 : Jika nilai chi-square hitung yaitu probabilitas $O b s^{*} R$-squared $>$ nilai kritis chi-square pada tabel dengan derajat kepercayaan tertentu menunjukkan ada heteroskedastisitas

\section{Uji Autokorelasi}

Autokorelasi adalah korelasi (hubungan) yang terjadi diantara anggota-anggota dari serangkaian pengamatan yang tersusun dalam rangkaian waktu (seperti pada data runtun waktu atau time series data) atau yang tersusun dalam rangkaian ruang (seperti pada data silang waktu atau cross-sectional data). (Sumodiningrat.2007).

Autokorelasi muncul karena observasi yang berurutan sepanjang waktu berkaitan satu sama lain. Masalah ini timbul karena residual (kesalahan pengganggu) tidak bebas dari satu observasi lainnya. Bila asumsi ini tidak dipenuhi maka dalam hal ini uji t dan uji $\mathrm{F}$ tidak lagi menjadi valid dan kurang kuat karena selang keyakinan akan semakin lebar. Autokorelasi mengakibatkan koefisien regresi yang dihasilkan tidak efisien sehingga menjadi tidak dapat dilakukan. Beberapa penyebab munculnya masalah autokorelasi dalam analisis regresi adalah: (Suliyanto.2011)

a. Adanya kelembaman (inertia).

b. Bias spesifikasi model kasus variabel yang tidak dimasukkan.

c. Manipulasi data (manipulation of data)

d. Adanya kelembanan waktu (time lags)

\section{Metode Lagrange Multiplier (LM Test)}

Pada penelitian ini digunakan metode pengujian Lagrange Multiplier atau uji Breusch-Godfrey Serial Correlation LM-Test untuk menguji adanya masalah autokorelasi tidak hanya pada derajat pertama (first order) tetapi juga digunakan pada berbagai tingkat derajat autokorelasi. Oleh karena itu banyak penulis yang menyatakan bahwa uji LM-Test lebih bermanfaat dibandingkan dengan uji DW. Dengan kata lain dinyatakan bahwa apabila nilai Probabilitas $O b s * R$-squared lebih besar dari tarif nyata tertentu (yang digunakan), maka persamaan ini dinyatakan tidak mengalami autokorelasi. Apabila nilai $O b s * R$-squared yang diperoleh lebih kecil dari pada taraf nyata tertentu maka persamaan tersebut mengandung autokorelasi. (Suliyanto.2011)

Langkah-langkah dari uji $L M$-Test sebagai berikut:

1. Membuat persamaan regresi

2. Mencari nilai perdiksinya dan diberi nama $\left(\hat{\mathrm{Y}}_{1}\right)$

3. Hitung nilai residual dengan notasi $\mu_{1}$.

4. Lakukan regresi dengan $\mu_{1}$ sebagai variabel terikat dan msukkan $\mu_{1-1}$ sebagai variabel bebas.

5. Menghitung nilai $X^{2}$ dengan rumus $X^{2}=(n-1) * R^{2}$.

6. Menarik kesimpulan dengan membandingkan $X^{2}$ hitung dengan $X^{2}$ tabel dengan $d f=(a, n-1)$.

\section{Uji Multikolinearitas}

Menurut Suliyanto (2011) multikolineritas berarti terjadi korelasi linear yang mendekati sempurna antar dua variabel bebas. Uji multikolineritas bertujuan untuk menguji apakah dalam model regresi yang terbentuk ada korelasi yang tinggi atau sempurna diantara variabel bebas atau tidak. Jika dalam model regresi yang terbentuk terdapat korelasi yang tinggi atau sempurna diantara variabel bebas maka model regresi tersebut dinyatakan mengandung gejala multikolinier.

Dalam penelitian ini, uji multikolinearitas dilakukan dengan menggunakan kaidah "auxiliary regression". Penggunaan kaidah ini dilakukan dengan cara meregres masing-masing variabel bebas dengan variabel bebas yang lain. Apabila hasil dari proses meregres masing-masing variabel bebas dengan variabel bebas yang lain tersebut menunjukkan adanya nilai standar error hitung yang lebih rendah dari nilai standar error model utama, maka dapat disimpulkan tidak terjadi multikolineritas antar variabel bebas. Untuk menguji ada tidaknya multikolinieritas dapat dilihat dari nilai R-Square, F-hitung, t-hitung serta standar error. 


\section{Pengujian Statistik (Goodnes Of Fit)}

\section{Uji Signifikansi Parameter Individu (Uji Statistik t)}

Nilai t hitung digunakan untuk menguji apakah variabel tersebut berpengaruh secara signifikan terhadap variabel tergantung atau tidak. Suatu variabel akan memiliki pengaruh yang berarti jika nilai t hitung variabel tersebut lebih besar dibandingkan dengan nilai t tabel (Suliyanto, 2011).

Untuk menghitung nilai t hitung digunakan rumus:

$$
t_{i}=\frac{b j}{S b j}
$$

Keterangan :

$\mathrm{t}=$ Nilai $\mathrm{t}$ hitung

$\mathrm{bj}=$ Koefisien regresi

$\mathrm{sbj}=$ Kesalahan baku koefisien regresi.

Dalam pengujian ini mula-mula ditentukan hipotesis nol atau null hypotesis (Ho) yang menyatakan bahwa masing-masing variabel penjelas tidak berpengaruh terhadap variabel yang dijelaskan secara individu. Kemudian $\mathrm{H}_{\mathrm{A}}$ yang menyatakan bahwa masing-masing variabel penjelas mempunyai pengaruh terhadap variabel yang menjelaskan secara individu.

\section{Uji Signifikansi Simultan (Uji Statistik F)}

Nilai F hitung digunakan untuk menguji ketepatan model (goodness of fit). Uji $\mathrm{F}$ ini juga sering disebut sebagai uji simultan, untuk menguji apakah variabel bebas yang digunakan dalam model mampu menjelaskan perubahan nilai variabel tergantung atau tidak. Untuk menyimpulkan model masuk dalam kategori cocok ( fit) atau tidak, kita harus membandingkan nilai $\mathrm{F}$ hitung dengan nilai $\mathrm{F}$ tabel dengan derajat kebebasan: df: a, (k-1), (n-k). Nilai Fhitung dapat diperoleh dengan rumus: (Suliyanto.2011)

Rumus nilai F hitung

$$
F=\frac{R^{2} /(k-1)}{\left(1-R^{2}\right) I(N-k)}
$$

Keterangan : $\mathrm{F}=$ Nilai $\mathrm{F}$ hitu

$\mathrm{R}^{2}=$ Koefisien determinasi

$\mathrm{N}=$ Jumlah observasi

$\mathrm{K}=$ Jumlah variable

Untuk mengetahui apakah semua variabel penjelas yang di gunakan dalam model regresi secara serentak atau bersama-sama berpengaruh terhadap variabel yang dijelaskan, digunakan uji statistik F,

\section{Uji Koefisien Determinasi $\left(\mathbf{R}^{2}\right)$}

Nilai $\mathrm{R}^{2}$ disebut juga koefisien determinasi. Koefisien determinasi bertujuan untuk mengetahui seberapa jauh kemampuan model regresi dalam menerangkan variasi variabel terikat. Nilai koefisien determinasi diperoleh dengan menggunakan formula :

$$
R^{2}=1-\frac{\sum e_{i}^{2}}{\sum y_{i}^{2}}
$$

Nilai koefisien determinasi berada diantara nol dan satu $\left(0<\mathrm{R}^{2}<1\right)$. Nilai $\mathrm{R}^{2}$ yang kecil atau mendekati nol berarti kemampuan variabel bebas dalam menjelaskan variabel terikat sangat terbatas. Sebaliknya nilai $\mathrm{R}^{2}$ 
yang mendekati satu berarti variabel bebas memberikan semua informasi yang dibutuhkan untuk memprediksi variabel terikat.

\section{HASIL PENELITIAN DAN ANALISIS}

\section{Pembahasan Hasil Penelitian}

Estimasi model penelitian adalah pembahasan model yang dianalisis secara statistik dan ekonomi berdasarkan model ekonometrika. Analisis dilakukan pada model pengujian data panel sehingga didapat suatu pembahasan yang spesifik terhadap masing-masing model. Berikut terlampir hasil regresi dengan menggunakan eviews:

Tabel 2 Model Utama

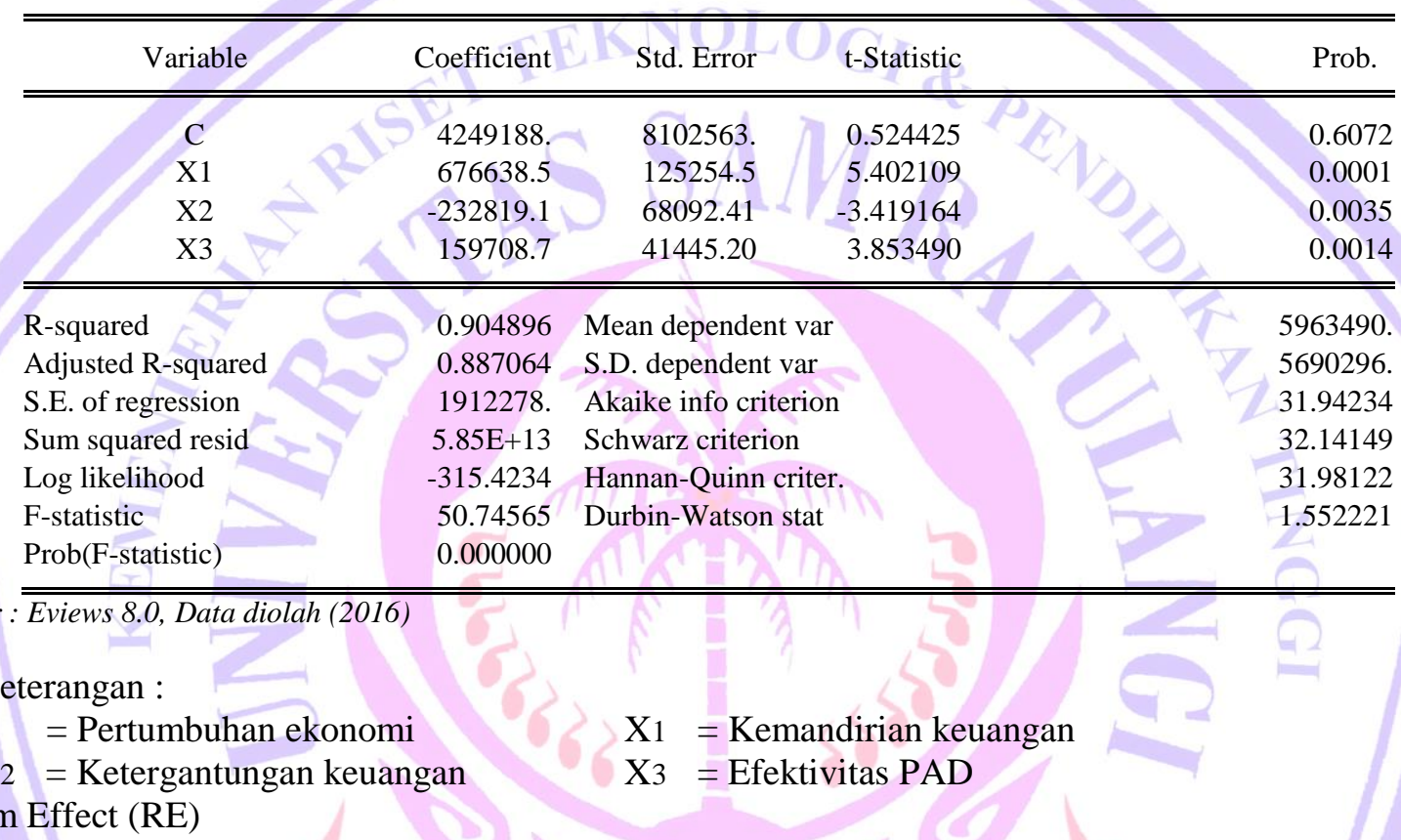

Sesuai dengan penjelasan pada bab sebelumnya, model analis yang digunakan dalam penelitian ini adalah random effect dengan menggunakan uji hausman untuk membandingkan model mana yang akan dipilih antara fixed effect dan random effect. Jika probilitas cross section random $>0,05$ maka menggunakan model random effect dan jika probilitas cross section fixed $<0,05$ maka harus menggunak model fixed effect. Dapat dilihat dalam estimasi uji hausman berikut:

Tabel 3 Estimasi Uji Hausman

Correlated Random Effects - Hausman Test

Equation: Untitled

Test cross-section random effects

\begin{tabular}{lccr}
\hline \hline Test Summary & Chi-Sq. Statistic & Chi-Sq. d.f. & Prob. \\
\hline \hline Cross-section random & 4.486102 & 3 & 0.2135 \\
\hline \hline
\end{tabular}

Sumber : Eviews 8.0, Data diolah (2016)

Dari hasil estimasi pada tabel 4.4 uji hausman dapat dilihat bahwa probabilitas cross section random $0,2135>0,05$ hal ini menunjukkan bahwa model yang akan digunakan adalah random effect. Berikut terlampir hasil estimasi random effect: 
Tabel 4 Estimasi Model Random Effect

\begin{tabular}{crrrr}
\hline \hline Variable & Coefficient & Std. Error & t-Statistic & Prob. \\
\hline \hline C & 4249188. & 7750610. & 0.548239 & 0.5911 \\
X1 & 676638.5 & 119813.8 & 5.647417 & 0.0000 \\
X2 & -232819.1 & 65134.66 & -3.574427 & 0.0025 \\
X3 & 159708.7 & 39644.93 & 4.028476 & 0.0010 \\
\hline \hline
\end{tabular}

\begin{tabular}{lll}
\hline \hline & Effects Specification & \\
& S.D. & Rho \\
\hline \hline Cross-section random & 2.536134 & 0.0000 \\
Idiosyncratic random & 1829214. & 1.0000 \\
\hline \hline
\end{tabular}

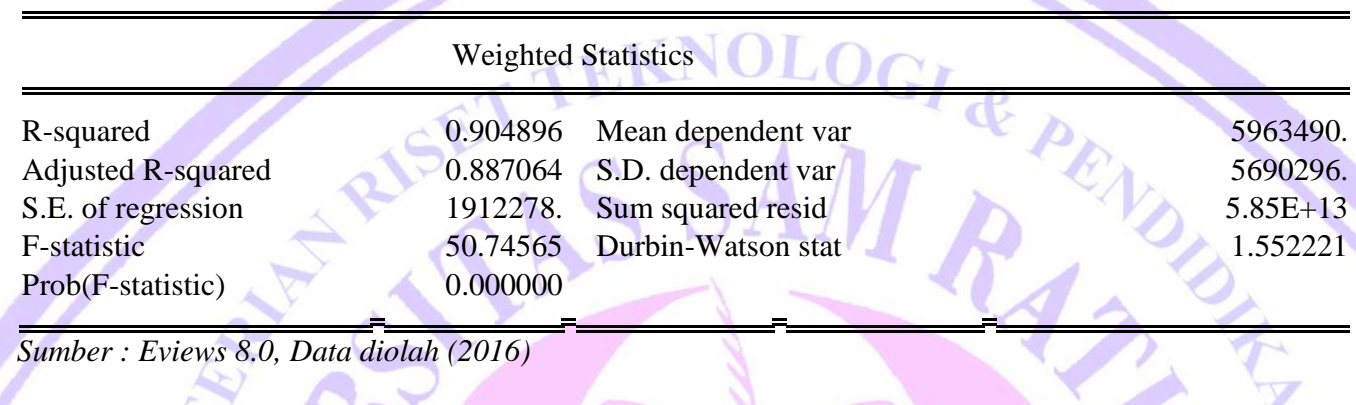

\section{Interpretasi model}

Berdasarkan hasil regeresi di atas dapat dijelaskan pengaruh variabel bebas kinerja keuangan (rasio kemandirian, rasio ketergantungan dan rasio efektifitas PAD) terhadap pertumbuhan ekonomi.

Rasio Kemandirian (X1) berpengaruh positif terhadap pertumbuhan ekonomi. Hal ini ditunjukkan oleh koefisien regresi rasio kemandirian (X1) yaitu sebesar (676638.5), artinya setiap kenaikan rasio kemandirian sebesar $1 \%$ maka pertumbuhan ekonomi akan naik sebesar $676638.5 \%$, ceteris paribus.

Rasio Ketergantungan (X2) berpengaruh negatif terhadap pertumbuhan ekonomi. Hal ini ditunjukkan oleh koefisien regresi rasio ketergantungan yaitu sebesar (-232819.1). Artinya setiap kenaikan ketergantungan keuangan sebesar $1 \%$ maka pertumbuhan ekonomi akan turun sebesar $232819.1 \%$, ceteris paribus.

Rasio efektifitas PAD (X3) berpengaruh positif terhadap pertumbuhan ekonomi hal ini ditunjukkan oleh koefisien regresi rasio efektifitas PAD sebesar (159708.7). artinya setiap kenaikan rasio efektifitas PAD sebesar $1 \%$ maka pertumbuhan ekonomi akan naik sebesar $159708.7 \%$, ceteris paribus.

\section{Pengujian Asumsi Klasik}

Agar hasil empirik diatas dapat diterima secara ekonometrik, maka diperlukan syarat BLUE (Best, Linear, Unbias, Estimator) dari metode kuadrat terkecil (OLS). Pengujian yang dilakukan dalam model antara lain : uji heteroskedastisitas, uji autokorelasi, uji multikolinearitas.

Pengujian ini dimaksudkan untuk mendeteksi ada tidaknya Multikolinearitas, Heteroskedastisitas, dan Autokorelasi dalam model yang estimasi, karena apabila terjadi penyimpangan terhadap asumsi klasik tersebut. Uji $\mathrm{t}$ dan uji $\mathrm{F}$ yang dilakukan menjadi tidak falid dan secara statistik dapat mengacaukan kesimpulan yang diperoleh dari buku ekonometrika.

Dengan kata lain, apakah hasil-hasil regresi telah memenuhi kaidah Best Linear Unbiased Estimator (BLUE) sehingga tidak ada gangguan serius terhadap asumsi klasik dalam metode kuadrat terkecil tunggal (OLS) yaitu masalah Heteroskedastisitas, Autokorelasi, dan Multikolinieritas

\section{Uji Heteroskedastisitas}

Uji Heteroskedastisitas bertujuan untuk menguji apakah dalam model regresi terjadi ketidaksamaan varian dari residual satu pengamatan ke pengamatan yang lain. Jika varian residual satu pengamatan ke pengamatan yang lain tetap, maka disebut Homokesdasitas dan jika berbeda disebut Heteroskedastisitas. 
Metode yang digunakan untuk mendeteksi adanya Heteroskedastisitas pada penelitian ini adalah pengujian White. Pengujian heteroskedastisitas dilakukan dengan bantuan program komputer eviews dan diperoleh hasil sebagai berikut:

\section{Tabel 5 Hasil Uji Heteroskedastisitas}

\begin{tabular}{llll} 
F-statistic & 13.77035 & Prob. F(9,10) & 0.0002 \\
Obs*R-squared & 18.50672 & Prob. Chi-Square(9) & 0.0297 \\
Scaled explained SS & 17.10761 & Prob. Chi-Square(9) & 0.0471 \\
\hline \hline R-squared & 0.925336 & Mean dependent var & $2.93 \mathrm{E}+12$ \\
Adjusted R-squared & 0.858138 & S.D. dependent var & $5.10 \mathrm{E}+12$ \\
S.E. of regression & $1.92 \mathrm{E}+12$ & Akaike info criterion & 59.71288 \\
Sum squared resid & $3.69 \mathrm{E}+25$ & Schwarz criterion & 60.21075 \\
Log likelihood & -587.1288 & Hannan-Quinn criter. & 59.81007 \\
F-statistic & 13.77035 & Durbin-Watson stat & 1.689684 \\
Prob(F-statistic) & 0.000158 & & \\
\hline \hline
\end{tabular}

Dari hasil yang terlampir diketahui bahwa koefisien determinasi $\left(\mathrm{R}^{2}\right)$ sebesar 0.925336 . Nilai Chi squares hitung sebesar 18.50672 yang diperoleh dari informasi Obs ${ }^{*} \mathrm{R}$-squared (jumlah observasi dikalikan dengan $\left(\mathrm{R}^{2}\right)$ ). Di lain pihak nilai Chi-squares tabel pada $\alpha=1 \%$ dengan df sebesar 9 adalah 21,67. Karena nilai Chisquares hitung Obs"R-squared lebih kecil dari nilai kritis Chi-squares tabel maka dapat disimpulkan tidak ada masalah heteroskedastisitas dan Ho diterima.

\section{Uji Autokorelasi}

Untuk mendeteksi masalah autokorelasi digunakan Uji Lagrange Multiplier. Jika hasil uji LM berada pada hipotesa nol $\left(\mathrm{H}_{0}\right)$ yaitu nilai chi squares hitung Obs*R-squared < dari pada nilai kritis chi squares tabel, maka model estimasi tidak terdapat autokorelasi, begitu pula sebaliknya jika berada pada hipotesa alternative $\left(\mathrm{H}_{1}\right)$ yaitu nilai chi squares Obs*R-squared $>$ dari pada nilai kritis chi squares tabel, maka terdapat autokorelasi.

Tabel 6 Hasil Uji Autokorelasi

Breusch-Godfrey Serial Correlation LM Test:

\begin{tabular}{lrlr}
\hline \hline F-statistic & 0.933783 & Prob. F(2,14) & 0.4162 \\
Obs*R-squared & 2.353941 & Prob. Chi-Square(2) & 0.3082 \\
\hline \hline R-squared & 0.117697 & Mean dependent var & $-2.64 \mathrm{E}-09$ \\
Adjusted R-squared & -0.197411 & S.D. dependent var & 1754826. \\
S.E. of regression & 1920241. & Akaike info criterion & 32.01712 \\
Sum squared resid & $5.16 \mathrm{E}+13$ & Schwarz criterion & 32.31584 \\
Log likelihood & -314.1712 & Hannan-Quinn criter. & 32.07544 \\
F-statistic & 0.373513 & Durbin-Watson stat & 1.942177 \\
Prob(F-statistic) & 0.858491 & & \\
\hline \hline
\end{tabular}

Sumber: Data diolah (2016)

Dari hasil regresi diatas dapat dilihat nilai koefisien determinasinya $\left(\mathrm{R}^{2}\right)$ sebesar 0.117697 . Nilai chi squares hitung Obs*R-squared sebesar 2.353941 sedangkan nilai kritis pada tabel chi-squared pada $\alpha=1 \%$ dengan df sebesar 2 adalah 9,21034. nilai chi squares hitung Obs*R-squared lebih kecil dari pada nilai kritis chisquares tabel, maka dapat disimpulkan model tidak mengandung masalah autokorelasi, maka Ho diterima.

\section{Uji Multikolinieritas}

Uji Multikolinieritas dilakukan untuk mengetahui ada tidaknya hubungan yang signifikan diantara variabel bebas. Deteksi adanya multikolinieritas dilakukan dengan melakukan regresi suatu variabel bebas terhadap variabel-variabel bebas yang lain dalam model. Untuk menguji ada tidaknya multikolinearitas dapat dilihat dari nilai R-Square, F-hitung, t-hitung serta standar error. 
$\mathrm{H}_{0}$ diterima jika $\mathrm{R}^{2}$ statik $<\mathrm{R}^{2}$ model utama. Hal ini menunjukkan bahwa tidak ada masalah multikolinearitas, dan jika $\mathrm{H}_{1}$ diterima maka $\mathrm{R}^{2}$ statik $>\mathrm{R}^{2}$ model utama. Hal ini menunjukkan bahwa ada masalah multikolinearitas.

Tabel 7 Hasil Uji Multikolinieritas

\begin{tabular}{|l|l|l|}
\hline Variabel & R2 Hitung & R2 Model utama \\
\hline X1 & 0.676261 & 0.904896 \\
\hline X2 & 0.578524 & 0.904896 \\
\hline X3 & 0.326886 & 0.904896 \\
\hline Sumber : Data Diolah (2016)
\end{tabular}

Dari tabel hasil analisis uji multikolinieritas diatas terlihat bahwa $\mathrm{R}^{2}$ statistik lebih kecil dari $\mathrm{R}^{2}$ model utama. $\mathrm{Hal}$ ini menunjukkan bahwa $\mathrm{H}_{0}$ diterima. Dengan diterimanya $\mathrm{H}_{\mathrm{o}}$ berarti tidak terdapat masalah multikolinearitas.

\section{Uji Kesesuaian (Test Goodness of fit)} Uji secara individual (Uji t)

Pengujian secara individual ini dimaksudkan untuk mengetahui apakah masing-masing variabel bebas berpengaruh secara signifikan terhadap variabel terikat. Uji ini dilakukan dengan melihat besarnya t hitung atau dengan melihat tingkat probabilitasnya. Pengujian ini dapat dilakukan dengan menggunakan kriteria pengujian sebagai berikut:

\section{Uji t pengaruh variabel X1 (rasio kemandirian) terhadap variabel Y (pertumbuhan ekonomi)}

Hasil regresi yang diperoleh menunjukkan uji t pada model sebesar (5.647417) dan nilai $t$ tabel dengan $\mathrm{df}=15, \alpha=1 \%$ adalah 2,947 berdasarkan data tersebut dapat diketahui bahwa t-hitung $>$ t-tabel (5.647417>2,947). Hal ini menunjukkan bahwa Ho ditolak. Dengan ditolaknya Ho, maka perubahan rasio kemandirian mempunyai pengaruh yang sangat signifikan secara statistik pada tingkat kepercayaan $99 \%(\alpha$ $=1 \%$ ) terhadap pertumbuhan ekonomi (PDRB).

Uji t pengaruh variabel X2 (rasio ketergantungan) terhadap variabel Y (pertumbuhan ekonomi)

Hasil regresi yang diperoleh menunjukkan uji $\mathrm{t}$ pada model sebesar $(-3.574427)$ dan nilai $\mathrm{t}$ tabel dengan $\mathrm{df}=$ $15, \alpha=1 \%$ adalah $(-2,947)$. Berdasarkan data tersebut dapat diketahui bahwa t-hitung $>\mathrm{t}$-tabel $3,303003>-2,947)$. Hal ini menunjukkan bahwa H0 ditolak. Dengan ditolaknya Ho, maka perubahan rasio ketergantungan mempunyai pengaruh yang sangat signifikan secara statistik pada tingkat kepercayaan $99 \%$ $(\alpha=1 \%)$ terhadap pertumbuhan ekonomi (PDRB).

Uji t pengaruh variabel X3 (rasio efektifitas PAD) terhadap variabel Y (pertumbuhan ekonomi)

Hasil regresi yang diperoleh menunjukkan uji t pada model sebesar (4.028479) dan nilai $t$ tabel dengan $\mathrm{df}=$ 15, $\alpha=1 \%$ adalah 2,947. Berdasarkan data tersebut dapat diketahui bahwa t-hitung > t-tabel (4.028479>2,947). Hal ini menunjukkan bahwa Ho ditolak. Dengan ditolaknya Ho, maka perubahan rasio efekifitas PAD mempunyai pengaruh yang sangat signifikan secara statistik pada tingkat kepercayaan $99 \%$ $(\alpha=1 \%)$ terhadap pertumbuhan ekonomi (PDRB).

\section{Uji Signifikansi Simultan (Uji Statistik F)}

Uji F-statistik dilakukan untuk mengetahui apakah variabel bebas secara bersama-sama berpengaruh terhadap variabel terikat. Pengujian ini dilakukan dengan membandingkan nilai F-hitung dengan nilai F-tabel pada derajat kebebasan (n-k-1) dan tingkat signifikansi $(\alpha)$ 1\%, 5\%, 10\%. Jika nilai F-hitung lebih besar dari nilai $\mathrm{F}$ tabel maka Ho ditolak dan Ha diterima. Artinya variabel bebas secara bersama-sama berpengaruh signifikan terhadap variabel terikat dan jika F-hitung lebih kecil dari nilai F-tabel maka Ho diterima dan H1 ditolak. Artinya variabel bebas secara bersama-sama tidak berpengaruh signifikan terhadap variabel terikat. Nilai F-tabel dengan derajat kebebasan $(\mathrm{df})=15$ dan $\alpha=1 \%$ adalah 14,20 . Dari hasil regresi diketahui bahwa nilai F-hitung adalah 50.74565. Dengan demikian F-hitung lebih besar dari nilai F-tabel, artinya secara bersama-sama variabel kinerja keuangan yang terdiri dari rasio kemandirian, rasio ketergantngan, dan 
rasio efektifitas PAD berpengaruh sangat signifikan terhadap pertumbuhan ekonomi Kota Manado, Bitung, Tomohon dan Kotamobagu.

\section{Koefisien Determinasi $\left(\mathbf{R}^{2}\right)$}

Koefisien determinasi $\left(\mathrm{R}^{2}\right)$ dilakukan untuk mengukur tingkat ketepatan/ kecocokan, yang merupakan persentase sumbangan dari variabel bebas terhadap variasi (naik turunya) variabel terikat secara bersamasama. Jika nilai $\mathrm{R}^{2}=1$, berarti besarnya persentase sumbangan kinerja keuangan yang terdiri dari rasio kemandirian keuangan, ketergantungan keuangan, dan efisiensi terhadap variasi (naik turunya) pertumbuhan ekonomi secara bersama-sama adalah $100 \%$. Dari hasil regresi diketahui bahwa nilai $\mathrm{R}^{2}$ adalah 0.904896 (90.48\%) yang berarti bahwa kontribusi atau sumbangan dari variabel bebas kinerja keuangan yang terdiri dari rasio kemandirian, rasio ketergantungan, dan rasio efektifitas PAD secara bersama-sama terhadap variasi naik turunya variabel pertumbuhan ekonomi (PDRB) adalah sebesar 90.48\%, sisanya 9,52\% disumbangkan oleh variabel lain yang tidak dimasukkan kedalam model.

\section{Pembahasan pengaruh variable bebas terhadap variable terikat}

Berdasarkan pembahasan yang telah dipaparkan sebelumnya variable terikat memiliki ketergantungan terhadap variable bebas dengan derajat konsentrasi masing-masing sesuai dengan tingkat pengaruh dari masing-masing variable apakah telah sesuai dengan hipotesi atau berlawanan dengan hipotesi. Adapun pembuktian berdasarkan hipotesis dan pengujian variable dapat diterangkan berdasarkan pembahasan berikut:

\section{Pengaruh rasio kemandirian terhadap pertumbuhan ekonomi}

Berdasarkan persamaan regresi, rasio kemandirian terhadap pertumbuhan ekonomi berpengaruh positif dan signifikan pada alfa $1 \%$ dengan tingkat kepercayaan sebesar $99 \%$. Hal ini ditunjukkan dengan nilai koefisien regresi rasio kemandirian sebesar (676638.5) artinya setiap kenaikan kemandirian keuangan sebesar $1 \%$ maka pertumbuhan ekonomi akan naik sebesar $676638.5 \%$, dengan asumsi ceteris paribus. Hal ini sesuai dengan hipotesis penelitian dimana jika rasio kemadirian meningkat maka akan meningkatkan output perekonomian. Hal ini juga sesuai dengan teori yang dikemukakan Tiebout (1961) bahwa sistem desentralisasi fiskal dimana pemerintah daerah memainkan peran yang lebih penting daripada pemerintah pusat dalam penyediaan pelayanan publik akan mendorong pertumbuhan ekonomi. Desentralisasi fiskal merupakan rasio yang mejelaskan kontribusi PAD terhadap total penerimaan daerah, semakin tinggi tinggi kontribusi PAD maka semakin tinggi kemampuan pemerintah dalam menyelenggarakan desentralisasi, artinya akan semakin mandiri perkotaan di Sulawesi utara dalam membiayayi kegiatan perekonomian dan pemerintahannya. Menurut Samimi (2010) menyatakan bahwa penelitian dilakukan karena pertumbuhan ekonomi dipandang sebagai tujuan dari desentralisasi fiskal dan efisiensi dalam alokasi sumberdaya disektor publik serta sebagai bagian dari tujuan pemerintah secara eksplisit untuk mengambil kebijakan-kebijakan yang mengarah pada peningkatan pendapatan perkapita. Menurut Davoodi dan Zou, (1998), desentralisasi fiskal adalah bagian dari reformasi peningkatan efisiensi di sektor publik dan peningkatan kompetisi antara pemerintah daerah dalam pemenuhan kebutuhan publik yang dalam menstimulasi pertumbuhan ekonomi. Hasil penelitian Amagoh dan Amin (2012) menyimpulkan bahwa perbaikan bentuk pemerintahan yang meningkatkan transparasi dan akuntabilitas dimana dilakukan dengan adanya otonomi daerah dan desentralisasi fiskal sebagai salah satu unsur utama, akan berdampak positif bagi pertumbuhan ekonomi. Penelitian ini juga ditunjang oleh penelitian yang telah dilakukan oleh Yuana (2015) tentang Kinerja Keuangan Daerah Terhadap Pertumbuhan Ekonomi Dan Ketimpangan Regional Di Era Desentralisasi Fiskal di Kabupaten/Kota Provinsi Jawa Timur yang menjelaskan bahwa adanya pengaruh langsung yang signifikan dan memberikan kontribusi yang positif terhadap pertumbuhan ekonomi daerah dikabupaten/kota Provinsi Jawa Timur antara kemandirian keungan dan pertumbuhan ekonomi. Rasio kemandirian ini akan meningkatkan PAD (Pendapatan Asli Daerah) di daerah tersebut. Dengan PAD yang tinggi ini akan memberikan perkembangan yang pesat karena daerah akan lebih maju dan berkembang perekonomiannya, sehingga akan mempengaruhi laju pertumbuhan ekonomi yang tinggi. Hasil penelitian ini juga lebih diperkuat dengan penelitian yang dilakukan oleh Ani dan Dwirandra (2014) yang memaparkan hasil penelitian variabel rasio kemandirian terhadap pertumbuhan ekonomi yang memiliki pengaruh yang positif 
dan signifikan, Ini berarti dengan semakin besarnya porsi PAD terhadap total pendapatan daerah maka akan semakin mendorong terjadinya pertumbuhan ekonomi di Kota Manado, Bitung, Tomohon, dan Kotamobagu.

\section{Pengaruh rasio ketergantungan terhadap pertumbuhan ekonomi}

Rasio ketergantungan dapat dihitung dengan membandingkan jumlah pendapatan transfer dengan total pendapatan daerah. Semakin tinggi rasio ini maka semakin besar ketergantungan daerah terhadap pemerintah pusat/provinsi. Untuk mendapatkan hasil estimasi yang sesuai dengan model ekonometrik harus dilakukan pengujian rasio kuangan dengan menggunakan program excel kemudian diestimasikan ke dalam model ekonometrik dengan menggunakan data panel pada eviews.

Berdasarkan hasil estimasi pada variabel rasio ketergantungan terhadap variabel pertumbuhan ekonomi menunjukkan adanya pengaruh yang negatif dan signifikan sebesar (-232819.1) pada alfa 1\% dengan tingkat kepercayaan 99\%, artinya setiap kenaikan rasio ketergantungan sebesar $1 \%$ maka pertumbuhan ekonomi akan turun sebesar $232819.1 \%$, dengan asumsi ceteris paribus. hal ini juga ditunjang dengan pengukuran uji t statistik dimana t-hitung lebih besar dari t-tabel $(-3.574427>-2,947)$ pada alfa $1 \%$ dengan derajat kepercayaan $99 \%$ yang menjelaskan adanya pengaruh yang sangat signifikan antara rasio ketergantungan dengan pertumbuhan ekonomi. Hal ini sesuai dengan hipotesis penelitian dimana jika rasio ketergantungan meningkat maka akan menurunkan laju pertumbuhan ekonomi, karena dengan dana transfer yang masih tinggi menyebabkan daerah tersebut memiliki ketergantungan dari pusat untuk mendanai atau membiayai kebutuhan daerahnya sehingga daerah tersebut belum mandiri untuk mengelola keuangannya, sehingga otonomi daerah belum berjalan sesuai dengan semestinya.

Penelitian ini juga didukung dengan penelitian yang dilakukan oleh Arsa (2015) mengenai Pengaruh Kinerja Keuangan Terhadap Alokasi Belanja Modal Dan Pertumbuhan Ekonomi Pemerintah Kabupaten/Kota SeProvinsi Bali Tahun 2006-2013 yang menjelaskan hasil analis pengaruh tidak langsung ketergantugan keuangan terhadap pertumbuhan ekonomi, hal ini dibuktikan dengan nilai $\mathrm{Z}$ sebesar $-2,840$ yang lebih besar dari 1,96 yang berarti bahwa secara tidak langsung ketergantungan keuangan melalui alokasi belanja modal berpengaruh negatif signifikan terhadap pertumbuhan ekonomi, Berdasarkan temuan tersebut memberikan indikasi bahwa dengan ketergantungan yang rendah maka semakin kecil ketergantungan daerah terhadap pemerintah pusat/provinsi, yang berarti kemampuan keuangan pemerintah daerah lebih baik. Dengan demikian pemerintah daerah dapat memacu pertumbuhan ekonomi daerahnya melalui alokasi belanja modal.

\section{Pengaruh rasio efektivitas PAD terhadap pertumbuhan ekonomi}

Dengan melihat persaamaan regresi yang telah dilakukan pada variable efektivitas terhadap pertumbuhan ekonomi berpengaruh positif dan signifikan pada alfa 1\% dengan tingkat kepercayaan $99 \%$ sebesar (159708.7), artinya setiap kenaikan rasio efektivitas sebesar 1\% maka pertumbuhan ekonomi akan naik sebesar $159708.7 \%$, dengan asumsi ceteris paribus. Hal ini telah sesuai dengan hipotesis dimana efektifitas berpengaruh positif terhadap pertumbuhan ekonomi, rasio efisiensi dilakukan untuk menunjukan keberhasilan dari segi tercapai dan tidaknya sasaran yang telah ditetapkan. Jika hasil kegiatan semakin mendekati sasaran, berarti semakin tinggi efektivitasnya. Penelitian ini juga didukiung oleh penelitian yang dilakukan oleh Arsa(2015) mengenai Pengaruh Kinerja Keuangan Terhadap Alokasi Belanja Modal Dan Pertumbuhan Ekonomi Pemerintah Kabupaten/Kota Se-Provinsi Bali Tahun 2006-2013 yang menjelaskan hasil analis pengaruh tidak langsung ketergantugan keuangan terhadap pertumbuhan ekonomi, hal ini dibuktikan dengan nilai $\mathrm{Z}$ sebesar 3,374 yang lebih besar dari 1,96. Hal tersebut membuktikan bahwa secara tidak langsung Efektivitas PAD melalui alokasi belanja modal berpengaruh terhadap pertumbuhan ekonomi.

\section{KESIMPULAN DAN SARAN}

\section{Kesimpulan}

Penelitian ini bertujuan untuk menguji dan memperoleh bukti empiris pengaruh kinerja keuangan terhadap pertumbuhan ekonomi perkotaan di Sulawesi Utara tahun 2010-2014, dan untuk menjawab pertanyaan dari rumusan masalah. Berdasarkan hasil analisis dan pembahasan pada bab sebelumnya diperoleh hasil sebagai berikut: 
1. Kinerja keuangan dengan rasio kemandirian berpengaruh positif dan signifikan terhadap pertumbuhan ekonomi perkotaan di Sulawesi Utara.

2. Kinerja keuangan dengan rasio ketergantungan berpengaruh negatif dan signifikan terhadap pertumbuhan ekonomi perkotaan di Sulawesi Utara.

3. Kinerja keuangan dengan rasio efektivitas terhadap pertumbuhan ekonomi perkotaan di Sulawei Utara berpengaruh positif dan signifikan.

Saran

1. Untuk penelitian berikutnya diharapkan dapat menambahkan rasio-rasio kinerja keuangan lainnya guna untuk melihat tingkat ketergantungan antara pertumbuhan ekonomi dan kinerja keuangan.

2. Peningkatan pertumbuhan ekonomi dapat didukung dengan peningkatan kemandirian keuangan daerah khususnya pada daerah yang memiliki rata-rata perubahan PDRB terbesar yaitu kota Bitung.

\section{DAFTAR PUSTAKA}

Adi, P. H. 2005. Dampak Desentralisasi Fiskal Terhadap Pertumbuhan Ekonomi. Jurnal Kritis. Universitas Kristen Satya Wacana Salatiga.

Adi, P. H. 2007. Hubungan Antara Pertumbuhan Ekonomi Daerah, Belanja Pembangunan Dan Pendapatan Asli Daerah (Studi pada Kabupaten dan Kota se Jawa-Bali), Jurnal Akuntansi dan Keuangan Sektor Publik. Vol 08. No. 1.

Ahmed Khattab, Juliot Mpabe B.M, dan Abid Ihadiyan. 2015. Financial Development, Financial Instability and Economic Growth: The Case Of Maghreb Countries. International Journal of Economic and Financial Issue. ISSN: 2146-4138

Amagoh F, Amin AA. 2012. An Examination Of The Impacts Of Fiscal Decentralization On Economic Growth. International Journal of Business Administrastion. 2(6):2012.

Ardi Hamzah, 2008. Analisis kinerja keuangan terhadap pertumbuhan ekonomi, pengangguran dan kemiskinan. Universitas Trunojoyo.

Arsa. 2015. Pengaruh Kinerja Keuangan Terhadap Alokasi Belanja Modal dan Pertumbuhan Ekonomi Pemerintah Kabupaten/Kota Se-Provinsi Bali 2006-2013. Tesis. Universitas Udayana. Bali.

Astuti, Wuku. 2015. Analisis Pengaruh Kinerja Keuangan Terhadap Pertumbuhan Ekonomi Dan Dampaknya Terhadap Pengangguran Dan Kemiskinan (Studi Pada Kabupaten Dan Kota Di Pulau Jawa Periode 2007-2011). Ebbank. Vol 6, No. 1, Universitas Widya Mataram. Yogyakarta.

Ani Nana Putri dan Dwirandra. Pengaruh Kinerja Keuangan Daerah pada Pertumbuhan Ekonomi, Pengangguran, dan Kemiskinan Kabupaten dan Kota. Universitas Udayana. Bali.

Badan Pusat Statistik, 2004-2014. Manado Dalam Angka.

Babajide, Adegboye, dan Omankhanlem. 2015. Financial Inclusion and Economic Growth In Nigeria. International Journal Of Economics And Financial Issue. ISSN: 2146-4138

BPKP, 2012. Petunjuk Penyusunan Kompilasi Laporan Keuangan dan Analisis Kinerja Keuangan Pemerintah Daerah (Revisi).

Davoodi H, Zou H. 1998. Fiscal decentralization and economic growth: a cross-country study. Journal of Urban Economics. 43(2):244-245.

Darise Nurlan, 2008. Akuntansi Keuangan Daerah (Akuntansi Sektor Publik). Jakarta: Indeks.

Darise Nurlan, 2009. Pengelolaan Keuangan Daerah, Pedoman Untuk Eksekutif dan Legislatif, Rangkuman 7 Undang-Undang, 30 Peraturan Pemerintah dan 15 Permendagri. Jakarta: Indeks.

Deddy, Solihin. 2004 tujuan otonomi daerah.

Gujarati, Damodar N. 2006. Dasar-dasar Ekonometrika Jilid 1 dan 2. Edisi Ketiga. Erlangga. Jakarta.

Gunantara dan Dwirandra. 2014. Pengaruh Pendapatan Asli Daerah dan Dana Alokasi Umum pada Pertumbuhsn Ekonomi dengan Belanja Modal sebagai Variabel Pemoderasi di Bali. Universitas Udayana.

Halim, Abdul.2004. Akuntansi Keuangan Daerah. Yogyakarta: UPP STIM YKPN.

Halim Abdul, 2007. Edisi Refisi Akuntansi dan Pengendalian Pengelolaan Keuangan Daerah. Jogjakarta: UPP STIM YKPN. 
Hasmiati Wa Ode, 2010. Analisis Tingkat Kemandirian Derah Terhadap Penerimaan Pendapatan Asli Daerah. Pada Pemerintah Kabupaten Wakatobi. Desentralisasi Tidak Diterbitkan: Kendari Fakultas Ekonomi Universitas Haluoleo.

Insukindro, Mardiasmo, Widayat, W., Jaya, W.K., Purwanto, B.M., Halim, A., Suprianto, J., Purnomo, A.B., 1994, Peranan dan Pengelolaan Keuangan Daerah Dalam Usaha Peningkatan PAD, Buku I, KKD FE UGM,Yogyakarta.

Lincoln. Arsyad, 1999, Ekonomi Pembangunan, Edisi 4 Cetakan Pertama, Yogyakarta, Penerbit Bagian Penerbitan Sekilah Tinggi Ilmu Ekonomi YKPN.

Lucky Dihan. 2013. Analysis Of The Effect Of Regional Financial Performance To Economic Growth and Poverty Throught Capital Expenditure (Case Study Of 38 Regiencies/ Cities in East Java Province). Vol.4, No.19,2013. ISSN 2222-1700.

Mochamad F Hidayat. 2013. Analisis pengaruh kinerja keuangan derah terhadap alokasi belanja modal. Universitas Brawijaya.

Ndlovu, Godfrey. 2013. Financial Sector Development And Economic Growth: Evidence From Zimbabwe. Vol.3, No.2,2013, pp. 435-446.

Panji Kartika Jaya dan Dwirandra. 2014. Pengaruh Pendapatan Asli Daerah pada Belanja Modal dengan Pertumbuhan Ekonomi Sebagai Variabel Pemoderasi. Universitas Udayana.

Prakosa Bambang Kesit, 2005. Pajak dan Retribusi Daerah. Yogyakarta: UD Press.

Puspitasari dan Sulindawati. 2015. Pengaruh Belanja Modal terhadap Pertumbuhan Kinerja Keuangan daerah dengan PAD sebagai variabel intervening. Universitas Pendidikan Ganesha Singaraja.

Radianto, Elia. 1997. Otonomi Keuangan Daerah Tingkat II, Suatu Studi di Maluku”. Jakarta : Prisma, No.3 Tahun XXVI, LP3ES.

Samimi AJ, Lar SKP, Haddad GK, Alizadeh M. 2010. Fiscal Decentralization and Economic Growth in Iran. Australian Journal of Basic and Applied Sciences. 4(11): 5490-5495.

Samuelson, P.A, dan Nordhaus, W, D. 2004. Ilmu Makroekonomi. Edisi XVII. alih bahasa Gretta dkk. Jakarta: PT Media Global Edukasi.

Setiaji, Wirawan, dan Priyo Hari Adi. 2007. Peta Kemampuan Keuangan Sesuda Otonomi Daerah: Apakah Mengalami Pergeseran (studi pada kabupaten dan kota se Jawa Bali), Simposium Nasional Akuntansi, Juli 26-28, Makssar

Sofyan Syafri Harahap. 2007. Teori Akuntansi. Jakarta : RajaGrafindo Persada.

Sukirno Sadono. 2006. Ekonomi Pembangunan: Proses, Masalah dan Dasar Kebijakan. Edisi II. Jakarta: Kencana.

Sukirno Sadono. 2000. Pegantar Teori Mikroekonomi. Jakarta : Raja Grafindo Persada

Sumodiningrat. 2007. Ekonometrika Pengantar. Edisi Kedua. BPFE. Yogyakarta.

Sularso dan Restianto. Pengaruh Kinerja Keangan Terhadap Alokasi Belanja Modal Dan Pertumbuhan Ekonomi Kabuaten/Kota Di Jawa Tengah. ISSN 2088-2106

Sulianto. 2011. EKONOMETRIKA TERAPAN : Teori dan Aplikasi dengan SPSS. CV. ANDI OFFSET.

Suci. 2013, Pengaruh kemandirian keuangan daerah terhadap pertumbuhan ekonomi dan kemiskinan kabupaten/ kota provinsi banten.

Tibeout CM. 1961. An Economic Theory of Fiscal Decentralization. National Bureau of Economiz Research. 1961: 79-96

Todaro, Michael P. and Stephen C. Smith. 2003. Pembangunan Ekonomi. Edisi 8.alih bahasa Haris Munandar. Jakarta: Erlangga

Todaro, Michael P. 1997. Pembangunan Ekonomi Di Dunia Ketiga. Edisi Ke Enam, Alih Bahasa : Drs. Haris Munandar, M. A., Jakarta: PT Gelora Aksara Pratama.

Thesaurianto, Kuncoro. 2007. Analisis Pengelolan Keuangan Daerah Terhadap Kemandirian Daerah. Universitas Diponegoro. Semarang.

Undang-undang No.22 Tahun 1999 Tentang Pemerintahan.

Undang-undang No.25 Tahun 1999 Tentang Perimbangan Keuangan Antara Pemerintah Pusat dan Daerah.

Undang-undang No.32 Tahun 2004 dan UU No.33 Tahun 2004 Tentang Otonomi Daerah 
Yildirim Selim, Ozdemir Bilge Kagan, dan Dogan Burhan. 2013. Financial Development and Eonomic Growth Nexus in Emerging European Economies: New Evidence From Asymmetric Causality. Vol.3, No.3, 2013, pp.710-722. ISSN: 2246-4138

Yoserizal, 2011. efektivitas dan Efisiensi Tugas Laporan Mata Research Operasional.www.scibid.com/../Beberapa-Pembgertian-Efektif-Dan-Efisiensi.

Yuana, Alfionita Putri. 2014. Analisis Kinerja Keuangan Daerah Terhadap Pertumbuhan Ekonomi dan Ketimpangan Regional Di Era Desentralisasi Fiskal (Studi Kabupaten / Kota Di Provinsi Jawa Timur Periode 2008-2012). Universitas Brawijaya. Malang

http://bappeda.manadokota.go.id/halkategori-29-2.html http://www.diassatria.com/analisis-regresi-model-data-panel/ http://ferdifadly.blogspot.co.id/2012/03/v-behaviorurldefaultvmlo.html http://manadokota.bps.go.id/linkTabelStatis/view/id/80 http://www.econjournals.com/index.php/ijefi/article/view/1154/pdf http://www.iiste.org/Journals/index.php/JEDS/article/view/9804 https://www.google.com/search?q=jurnal+kinerja+keuangan\&ie=utf-8\&oe=utf $\underline{8 \# q=j u r n a l+\text { pertumbuhan+ekonomi+daerah }}$ https://www.google.co.id/ https://www.academia.edu/10785908/TINJAUAN_TEORI_OTONOMI_DAERAH 